\title{
Combining market structure and econometric methods for price transmission analysis
}

\author{
Alejandro Acosta ${ }^{1}$ (D) $\cdot$ Rico Ihle $^{2} \cdot$ Stephan von Cramon-Taubadel ${ }^{3}$
}

Received: 8 February 2018 / Accepted: 5 July 2019 / Published online: 15 August 2019

(C) FAO 2019

\begin{abstract}
Much attention has been devoted in the literature to the analysis of price transmission along food supply chains. Price transmission analysis has traditionally focused on applying econometric methods to assess price dynamics and interrelationships. However, the exclusive application of econometric methods without considering the market's institutional context has limited potential to support evidence-based policy-making. In recent years, studies have thus attempted to combine the use of quantitative and qualitative methods to better understand the level of performance of food value chains. This study contributes to broadening these empirical toolkits by suggesting a structured analytical framework that benefits from the simultaneous application of econometric and market-structure methods in price transmission analysis. To illustrate the application of the framework, we analyzed the milk market of Panama.
\end{abstract}

Keywords Price Transmission $\cdot$ Market Structure $\cdot$ Food Price Formation $\cdot$ Food Policy Design

JEL classification Q13 · C59 · D40

\section{Introduction}

The structure, performance and degree of price transmission (PT) in agrifood value chains has important welfare effects on consumers and producers (Sexton and Lavoie 2001; McCorriston 2013). Recent research (Dawe and Maltsoglou 2014; Luckmann et al. 2015; Usman and Haile 2017) highlights the relevance of understanding the dynamics of food prices for analyzing the effects of policy measures on food security. In particular the magnitude, speed, and symmetry with which price changes in one market are transmitted to another can have direct and indirect effects on all four dimensions of food security in both the short and the long term (FAO 2012).

Alejandro Acosta

alejandro.acosta@fao.org; alejandroacostaavila@gmail.com

1 Animal Production and Health Division, Food and Agriculture Organization of the United Nations, Rome, Italy

2 Agricultural Economics and Rural Policy Group, Wageningen University, Wageningen, The Netherlands

3 Department of Agricultural Economics and Rural Development, University of Göttingen, Göttingen, Germany
In the short-term, direct effects of this transmission on prices and the resulting incentives for supply and demand can affect food availability, access, price stability, and shift food use preferences. In the long term, domestic factors of production such as land, labour and capital can move towards new equilibria due to factor price adjustment, causing indirect dynamic effects on land use, production structures, dietary patterns, employment, and income (FAO 2012). These issues have focused attention on PT analysis not only from researchers but also policy makers (OECD 2015).

Since the early 1990s most PT analyses have used different specifications of the (vector) error-correction model (VECM/ECM) introduced by Granger (1981) and Engel and Granger (1987). In these models, the relationship between price series are influenced by the magnitude of deviations from their long-run equilibrium relationship (Enders 1998). In recent years, more flexible non-linear models have been suggested by several authors (e.g., by Serra and Goodwin 2002; Hassouneh et al. 2010; Busse et al. 2012; Würriehausen et al. 2015). Comprehensive reviews of PT analytical methods are provided, for example, by Fackler and Goodwin (2001), Meyer and von Cramon-Taubadel (2004), Frey and Manera (2007), Bakucs et al. (2014), von Cramon-Taubadel (2017), and Lloyd (2017). 
Although the variability and flexibility of the modeling toolset has greatly evolved, less attention has been devoted to improving the integration of insights and the understanding of market structure into PT analyses. In their review of the empirical literature addressing vertical and spatial PT, Goodwin and Vavra (2009) emphasize that the evaluations of price transmission are not likely to be very informative without a wider understanding of the market structure and institutions underlying the price data. Miller and Hayenga (2001) note that insights from econometric methods are often limited because plausible explanations of price behavior cannot be discovered based on price data alone. Lloyd (2017) stresses that while PT parameters are valuable descriptive determinants of price adjustments, one should be wary of inferring too much about the competitive setting of the market analyzed based on these parameters alone.

Acknowledgment of these issues has stimulated various authors (Kim and Cotterill 2008; Brümmer et al. 2009; Ihle et al. 2012; Fabinger and Weyl 2013; Hovhannisyan and Bozic 2014) to incorporate information about market structure into PT analyses. This study aims to advance this literature by examining how to combine market structure and time-series methods systematically in PT analysis. The analytical framework is composed of three steps: Step 1 uses market-structure analysis to obtain detailed insight into the organization of the market of interest. Step 2 employs time-series econometric methods to evaluate the price dynamics between actors along the supply chain. Step 3 triangulates the results obtained from both analyses to increase the understanding of the factors that influence price transmission.

The presented framework provides a constructive approach for complementing quantitative price analysis with information on the institutional structure of the market of interest. Thus, with this paper, we contribute to a growing literature that includes, for example, Davenport and Funk (2015) and König et al. (2017), and that combines quantitative and qualitative methods to assess the performance of food value chains. To illustrate the application of this framework, we analyzed the milk market in Panama.

\section{Market structure as a key ingredient of Price transmission analysis}

Many studies emphasize the central role that market structure plays in analyzing the degree of PT in food markets (McCorriston et al. 1998; Peltzman 2000; Carlton and Perloff 2004; Armstrong and Porter. 2007; Bakucs et al. 2014; Lloyd 2017). Some publications highlight that it is imperative to understand the institutional setting in which PT takes place, if findings from PT analyses are to be interpreted and understood appropriately (e.g., Goodwin and Vavra 2009). Market-structure analyses have extensively applied the use of structure-conductperformance (SCP) approaches to analyze causal relationships that run between industry concentration, the pricing behavior of firms, and profitability (Sutton 1991). Many economists criticize the SCP approach for being descriptive rather than analytical, arguing that market-structure studies should employ pricetheory models of the new empirical indusrial organisation (NEIO) literature based on the explicit, maximizing behavior of firms (Carlton and Perloff 2004).

One of the first studies to use NEIO methods in PT analysis is that of Gardner (1975), who analyzed the farm-retail price spread in the food industry. Based on a structural model of demand and supply for two inputs and one output under perfect competition, the author derived several elasticities to investigate how PT changed when food demand, farm product supply, or marketing input supply shifts occured. His analysis shows that the PT elasticity depends on whether the exogenous shock that generates the change in the market comes from the demand or the supply side. McCorriston et al. (1998) and Weldegebriel (2004) built on this model but accounted as well for market power in the food chain.

Bulow and Pfleiderer (1983) showed that PT is affected not only by elasticities of demand and supply but also by the shape of the demand and supply curves. However, Fabinger and Weyl (2013) demonstrated that while PT is determined by the elasticity of supply and demand and the curvature of the demand curve under imperfect competition, under constant returns to scale, only the curvature of demand plays a role. Kim and Cotterill (2008) pointed out that in differentiated product markets the shape of the demand curve depends on the empirical distribution of consumer characteristics. Hovhannisyan and Bozic (2014) showed that prices may respond only partially to shocks when demand becomes increasingly more elastic at higher price levels.

Recent studies have highlighted the interaction between vertical and horizontal structures in determining PT. Bonnet and Réquillart (2013) assessed the PT of a cost change considering horizontal and vertical interactions between manufacturers and retailers. Hong and Li (2017) developed a model to assess simultaneous interaction between horizontal and vertical market structure and the resulting effects on PT from commodity to wholesale prices and from wholesale to retail prices. Their results highlight the ambiguous effects derived from these interactions, showing that greater vertical integration raises PT but simultaneous increases in market share lower it. In summary, there is increasing recognition in the literature that market structure has manifold implications for the nature of price transmission, and that a particular type of observed PT behavior can result from different underlying market structures.

\section{Methodology}

We propose an analytical framework composed of three steps, each of which has several tasks (Fig. 1). Step 1 consists of 
analyzing the structure of the market of interest to obtain detailed insights into its organization. The first task of Step 1 (1.1) is to develop propositions to guide the data collection process, inform the design of the econometric model, and allow the study to link the empirical results with theory. The second task (1.2) is to map the supply chain to assess the structure of the market and to identify the interlinkages between firms and the flow of products. The third task (1.3) is to define the specific actors of interest; for example, in our empirical application below we focus on interactions between small producers and wholesalers. The fourth task (1.4) is to collect evidence using various qualitative sources of information including documentation, newspaper articles, semi-structured interviews, and focus group discussions, as in Yin (2013).

In Step 2, time-series econometric methods are used to analyze the price dynamics among the actors of interest. The first task of Step 2 (2.1) is to determine whether the series are stationary or nonstationary and, therefore, to test for unit roots. A standard Augmented Dickey Fuller (ADF) test can be used to test for unit roots, while also considering the potential presence of structural breaks in the series (Perron 1989; Saikkonen and Lütkepohl 2002; Wang and Tomek 2007). The second task (2.2) is to test for structural stability, as a fundamental assumption of most PT models is that the parameters remain constant throughout the sample period. If both series are integrated of order one, the third task (2.3) is to test for cointegration, for example using the methods proposed by Johansen (1991). If no evidence against cointegration is found, the fourth task (2.4) is to build the time-series econometric model to assess the price dynamics between the series, ideally ensuring that crucial characteristics of the market are reflected.

Finally, in Step 3, the different sources of information are combined to improve our understanding of the factors that influence PT. The first task (3.1) of Step 3 is to bring together the evidence derived from both analyses. The second task (3.2) is to identify potential interrelations among the results of the market structure and econometric analysis. The third task (3.3) is to link the evidence of both analyses with the propositions formulated in Step 1 and draw conclusions about the market structure and performance. We follow Yin (2013) in triangulating the results of these steps.

\section{Application to the case study}

To illustrate the application of the framework, we analyzed the milk market in Panama. In Panama, newspaper articles that started appearing in 2006 highlighted the lack of transparency in the dairy market and suggested that processors were colluding on the farm-gate prices paid to milk producers. This motivated the national antitrust authority to launch an investigation against a group of industrial processors over the alleged abuse of market power. The investigation found that four major milk processors had shared information that ultimately led them to collude on setting the purchase price of milk paid to producers.

The market-structure analysis was conducted using various sources of information, including a competitiveness analysis of the dairy sector, value chain studies, official government reports, and two major national newspapers (La Prensa and Panamá América). We carried out semi-structured interviews with key public and private actors active in the dairy chain, including two retailers, three industrial milk processors, five traditional milk processors, and ten milk producers. Two focus group discussions were organized with key stakeholders involved in the milk supply chain, including the Panamanian Livestock Dairy Institute, and the Livestock National Producers Association.

The time-series analysis was conducted using 252 monthly observations of fresh whole milk prices at the producer and wholesale levels between January 1991 and December 2013. These data were provided by the Agricultural Information System of the Contraloría General de la República de Panamá (CGRP). In this application, the assessment of the effects of changes in market structure on the price relationship between producers and wholesalers is of interest. Thus, following Esposti and Listorti (2013), and based on the results of

Fig. 1 PT analytical framework

\begin{tabular}{|c|c|c|}
\hline \multicolumn{3}{|l|}{ 1. Market Structure Analysis } \\
\hline \multirow{3}{*}{$\begin{array}{ll}1.1 & \begin{array}{l}\text { Develop preliminary } \\
\text { propositions. }\end{array} \\
1.2 & \begin{array}{l}\text { Map the structure of the } \\
\text { market. }\end{array} \\
1.3 & \begin{array}{l}\text { Define specific actors } \\
\text { of interest. }\end{array} \\
1.4 & \begin{array}{l}\text { Collect evidence using } \\
\text { market analayis } \\
\text { methods. }\end{array} \\
\end{array}$} & \multicolumn{2}{|c|}{ 2. Time-series Econometric Analysis } \\
\hline & \multirow{3}{*}{$\begin{array}{ll}2.1 & \text { Test for unit roots. } \\
2.2 & \text { Test for structural } \\
& \text { breaks. } \\
\text { 2.3 } & \text { Test for cointegration } \\
2.4 & \text { Build the econometric } \\
& \text { model with information } \\
& \text { from the market } \\
\text { structure analysis. }\end{array}$} & 3. Triangulation Analysis \\
\hline & & \begin{tabular}{|l}
3.1 Bring together the \\
evidence derived from \\
both analyses. \\
3.2 Identify potential \\
interrelations among the \\
results.
\end{tabular} \\
\hline & & $\begin{array}{l}\text { 3.3 Draw conclusions about } \\
\text { market structure and } \\
\text { performance. }\end{array}$ \\
\hline
\end{tabular}


Table 1 Propositions

\begin{tabular}{ll}
\hline Proposition & Description \\
\hline Proposition 1 & The market structure is characterized by oligopsonistic competition. \\
Proposition 2 & Oligopsonistic market power dampens price transmission. \\
Proposition 3 & The price spread narrows when the market becomes more competitive. \\
\hline
\end{tabular}

Source: Authors

the qualitative analysis described above, we specified a VECM in which a structural change dummy variable influences the constant term of the cointegration relationship. The VECM is specified according to Eq. (1).

$\Delta p_{t}=\alpha\left[\beta p_{t-1}+\mu+\delta D_{c t-1}\right]+\sum_{i=1}^{n} \Gamma_{i} \Delta p_{t-i}+\varepsilon_{t}$

The variable $p$ is a vector containing the producer and wholesaler prices in logarithms, $\alpha$ is the loading matrix that reflects the speeds at which the prices adjust to correct deviations from a long-run equilibrium. The parameter $\beta$ represents the cointegrating vector quantifying the prices' long-term equilibrium relationship, and $\mu$ is the intercept term, which captures all the elements that contribute to the magnitude of the price spread between producers and wholesalers. $D_{c}$ is a structural change dummy variable that takes the value of zero from January 1991 to December 2005, and one from January 2006 to December 2013. The parameters $\Gamma_{i}, i=1, \ldots n$ contain the autoregressive short-term parameters.

\section{Results}

\subsection{Market-structure analysis}

The first task of our analysis was to develop a set of specific propositions. The literature review yielded the propositions described in Table 1. These propositions serve to guide the direction and scope of the market-structure analysis in the form of interviews and focus group discussions, and thus inform the design of the econometric model and the corresponding data collection.

As illustrated in the mapping of the milk market structure in Fig. 2, Panama produces approximately 206 million $\mathrm{kg}$ of fluid milk equivalent (FME), imports 112 million FME, and exports 22 million FME. Thus, the total milk availability is approximately 296 million FME, and the import dependency ratio is $38 \%$. Average consumption per capita is 771 per year. In 2013, total FME imports amounted to US \$104 million, of which cheese accounted for $53 \%$, milk powder for $26 \%$, butter for $8 \%$, whey for $6 \%$, yogurt for $5 \%$ and fluid milk and cream for $3 \%$. The export of dairy products in Panama has been relatively low. In 2013, the country's FME exports amounted to US \$11.5 million, $73 \%$ of this total value was milk powder, and $27 \%$ was cheese. Due to tariff preferences obtained under the free trade agreement with other Central American countries, dairy exports went mainly to Costa Rica, El Salvador, Guatemala, Honduras, and Nicaragua.

As shown in Fig. 2, there are approximately 6,630 dairy farmers in Panama. Of these, $6 \%$ produce milk of grade A, $4 \%$ produce milk of grade $\mathrm{B}$, and $90 \%$ produce grade $\mathrm{C}$ milk. Of the 206 million $\mathrm{kg}$ of milk the country produced in $2013,46 \%$ was grade A, $6 \%$ was grade B and $48 \%$ was grade C. Grades $\mathrm{A}$ and $\mathrm{B}$ are used to supply the domestic market with fresh milk, whereas grade $\mathrm{C}$ is used mainly for industrial purposes, the manufacturing of traditional cheese, and self-consumption at the farm level. Of the total domestic supply, 75\% goes to industrial processors, $15 \%$ to traditional processors, and the remaining $10 \%$ is directly consumed by households.

There are six major milk processing companies in Panama. Figure 2 shows that in 2013, the concentration ratio $\left(C R_{4}\right)$ of the four largest processors (Estrella Azul, Nestle, Nevada, and Bonlac) was $90 \%$. In the last ten years, the Panamanian dairy processing sector has experienced several consolidations. For example, Coca-Cola Fomento Económico Mexicano S. A (FEMSA) acquired Estrella Azul, the cooperative Dos Pinos from Costa Rica acquired Nevada, and the company Castillo Hermanos from Guatemala acquired Bonlac. These recent developments have led to changes in the structure of the market, not only due to the increase in the size of operations but also because of the type and quality of raw products they demanded.

Visual inspection of the price series in Fig. 3 shows that producer (PP), wholesale (WP), and global (GP) milk prices were relatively stable between 1995 and 2005, moving constantly around approximately US\$ 25 cents per liter. ${ }^{1}$ The graph also reveals that milk prices increased and became more volatile after 2006. The increase in PP in 2007 can be partially explained by the 2006-08 world food crisis. Acosta et al. (2014) showed that the global price fluctuations during this period were transmitted to the domestic milk market in Panama. However, Fig. 3 also reveals three episodes in which WP and PP appeared to be moving independently. In some periods PP was higher than WP, which is unexpected. In 2006 WP increased while PP remained below $0.3 \mathrm{US} \$ /$ litre, but in 2007 PP increased strongly while WP remained comparatively stable. In 2009 WP again increased much more strongly

\footnotetext{
${ }^{1}$ US\$ represent American dollar
} 
Fig. 2 Structure of the milk market in Panama (data for 2013)

Source: Authors based on data from MIDA 2011; Contraloría General de la República de Panamá (CGRP). 2011; and INEC 2014

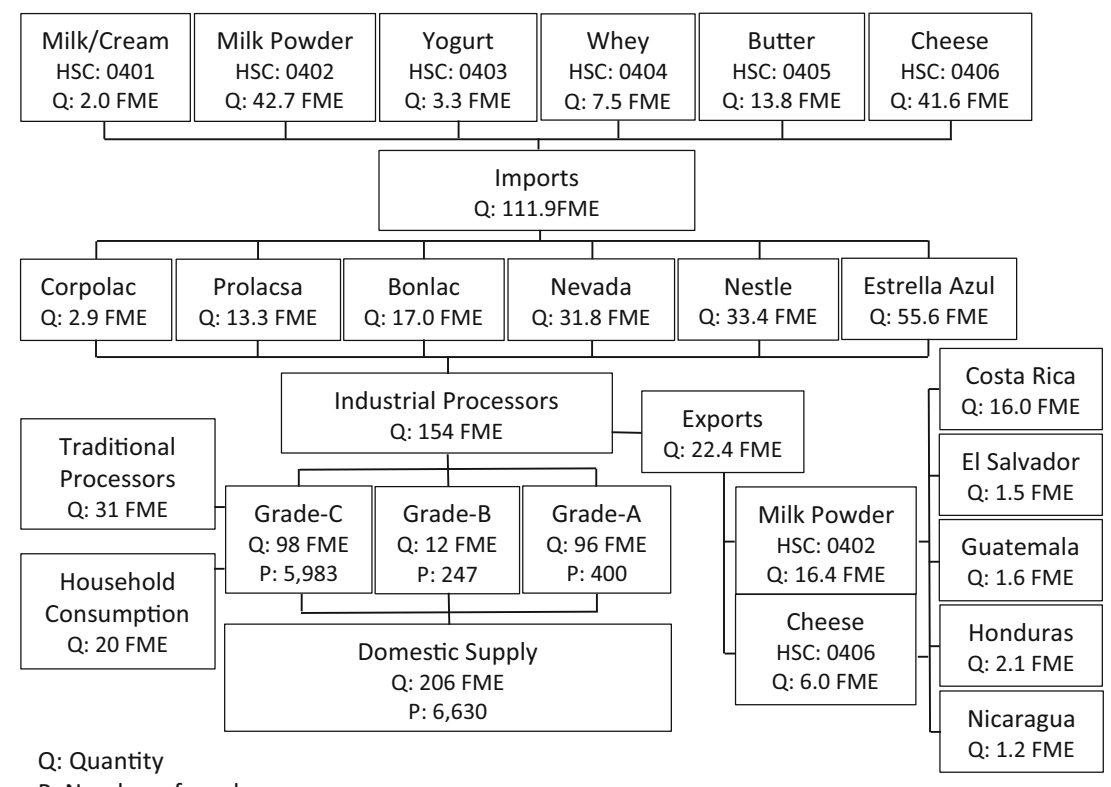

P: Number of producers

FME: Fluid milk equivalents/million kg than PP. This behavior suggests that major changes in the structure of the market might have been taking place.

The results of the media search (Table 2) reveal that milk producers and industrial processors of milk confronted each other regarding the oligopolistic practices that industrial processors were suspected of using. An article, published in January 2006 (Berrocal 2006) highlights that one of the biggest multinational dairy companies in Panama raised the price of dairy products to consumers. The article indicates that a price list was sent by this multinational company to all supermarkets informing them about the increase in prices. Other dairy companies also considered increasing their prices. Milk producers complained that the farm-gate prices that they received for milk remained constant at $0.20 \mathrm{US} \$ /$ litre although processors increased dairy prices for consumers by between 0.01 and $0.10 \mathrm{US} \$ /$ litre. Producers demanded that industrial processors increase the farm-gate price of raw milk, accusing them of using market power practices (Guerra 2006a), and asked the National Authority for Consumer Protection
(ACODECO) to look into possible price agreements among the few large-scale industrial dairy processors (Guerra 2006b).

In 2007 milk producers warned of an impending increase in consumer's milk prices, but claimed that they were not responsible for this increase (Tapia 2007a). Producers threatened processors with strike actions if milk prices were not increased by 0,09 US\$/ litre (Torres 2007). The companies did not meet this demand (Tapia 2007b), offering a price rise of $0,03 \mathrm{US} \$ /$ litre instead. Producers accepted the offer but indicated that they were exploring other actions to ensure more competitive prices (Tapia 2007c). In March 2008, ACODECO sued four major industrial processors for the presumed use of market power practices to reduce prices paid to milk producers (De Gracia 2008).

The semi-structured interviews highlighted that the articles which appeared in various newspapers in 2007 motivated ACODECO to open an investigation against four industrial dairy processors due to presumed collusion. The investigated processors were found guilty of having abused their market
Fig. 3 Producer, wholesale, and global milk prices. Source: Authors based on price data from Contraloría General de la República de Panamá (CGRP). (2014)

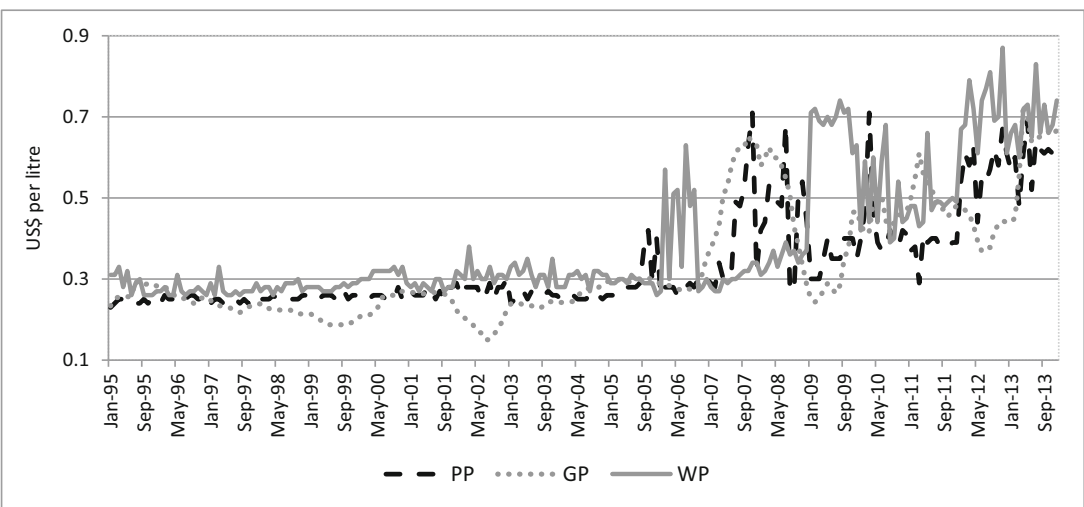


Table 2 Media search timeline results

\begin{tabular}{llll}
\hline Timeline & News headlines & Newspaper \\
\hline 12 Jan. 2006 & $\begin{array}{l}\text { While major dairy processors in Panama increased milk prices at consumer level, producer } \\
\text { prices remained constant. }\end{array}$ & La Prensa \\
12 Oct. 2006 & $\begin{array}{l}\text { Milk producers requested that industrial processors adjust the prices paid for raw milk at the farm gate level } \\
\text { 22 Nov. 2006 }\end{array}$ & $\begin{array}{l}\text { Producers accused industrial processors of oligopoly behaviour, fixing the price per liter of raw } \\
\text { milk paid to producers }\end{array}$ & La Prensa \\
22 May 2007 & $\begin{array}{l}\text { Producers threatened industrial processors with strike action if raw milk prices were not adjusted. } \\
\text { 7 Jun. 2007 }\end{array}$ & $\begin{array}{l}\text { Producers accepted a price increase offered by industrial processors, but point out that they would } \\
\text { explore other actions to ensure more competitive prices }\end{array}$ & La Prensa \\
8 Mar. 2008 & $\begin{array}{l}\text { Four major dairy processors were sued for the alleged abuse of market power. A fine of US \$100,000 } \\
\text { was imposed on each of the companies involved and an audit process was established }\end{array}$ & Panamá América \\
\hline
\end{tabular}

Source: Authors

power. The evidence gathered revealed that they had exchanged information that ultimately led to them setting lower farm-gate prices for raw milk. As a result, a fine of US\$ 100,000 was imposed on each of the companies involved and an audit process was established. The interviews also revealed that while the fear of being sued for collusion has discouraged the manipulation of prices, the lack of antitrust legislation to address violations of competitive market behavior has resulted in the use of other practices, such as the establishment of exclusivity agreements or the use of boycotts to limit market entrance by potential competitors. Both types of practices are more challenging to investigate and monitor.

Milk producers noted during the focus group discussions that milk prices regularly increase in Panama during the dry season between January and May and decrease during the rainy season between June and December. Milk producers also expressed their worries about the asymmetric change in fluid milk prices between consumers and producers. Producers stated that some of the following factors might be affecting PT in the milk supply chain:

- the presence of many poorly organized milk producers facing a small number of industrial processors, leading to low bargaining power of milk producers;

- the high perishability of milk, which restricts the geographic movement of raw milk and forces producers to sell their output to local milk collectors, even if more distant collectors offer higher prices;

- the fear of potential substitution by an alternative supplier if producers reduce their deliveries below a certain level;

- a large proportion of fixed and specific inputs that prevent a low-cost reallocation of capital resources in the short run, leading to a low price elasticity of supply.

During the semi-structured interviews, traditional milk processors reported that they purchase raw milk to process it into different types of cheese for local markets, especially mozzarella. The prices they pay milk producers are often two cents above the prices paid by the large industrial processors. However, the volume that the traditional processors can absorb is limited and determined by the size of the cheese market. When milk prices fall, the retail price of mozzarella follows suit, which increases the demand for mozzarella and, by extension, the traditional processors' demand for raw milk. Thus, when milk prices decrease below a certain threshold, small milk producers partially shift the supply of raw milk from wholesalers to traditional factories (Fig. 4). This scheme has become a buffer mechanism to smooth milk price reductions.

Finally, the semi-structured interviews with industrial processors revealed that industrial milk processors in Panama demand fluid milk of grade $\mathrm{C}$ as input to produce ice cream and butter. The price paid to milk producers considers the quality grade of the product (whether milk is of grade A, B, or $\mathrm{C}$ ), the international price of milk powder, and whether the dry or rainy season is currently prevailing. Most processors hold between two and three months of milk powder stocks, which enables them to smooth the prices that they pay milk producers and charge retailers. Stocks are usually lower during the dry season and higher during the rainy season, and processors therefore claim that they pay slightly higher prices to milk producers during the dry season, confirming what was reported by the milk producers above. In an initial specification of our empirical model we included seasonal effects to account for this, but these effects were not statistically significant. Hence, we do not include seasonal effects in the results presented below.

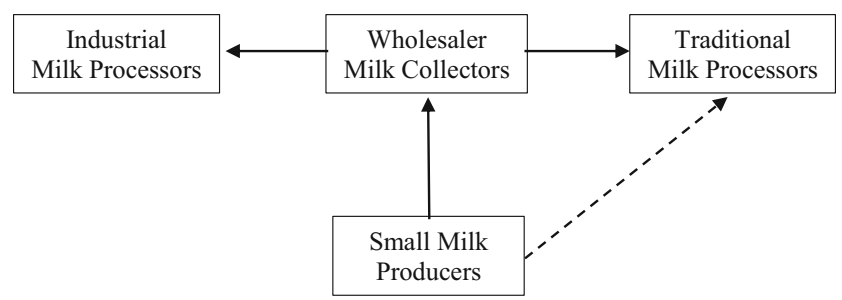

Fig. 4 Small milk producers supply network in Panama. Source: Authors 
Table 3 Results of the unit root tests

\begin{tabular}{lllllll}
\hline Test & Variable & Break & Lags & $H o: \gamma \approx I(0)$ & $H o: \Delta \gamma \approx I(0)$ & Critical Values at $5 \%$ \\
\hline ADF & WP & - & 2 & -1.26 & -9.27 & -2.86 \\
& PP & - & 3 & -0.91 & -6.38 & -2.86 \\
ADF Intercept/trend & WP & - & 2 & -2.54 & -8.62 & -3.41 \\
& PP & - & 3 & -3.10 & -4.72 & -3.41 \\
URSB shift & WP & $2006 \mathrm{M} 2$ & 2 & -2.54 & -10.21 & -2.88 \\
& PP & $2006 \mathrm{M} 1$ & 3 & -0.16 & -6.93 & -2.88 \\
URSB shift/trend & WP & $2006 \mathrm{M} 2$ & 2 & -2.68 & -10.22 & -3.03 \\
& PP & $2007 \mathrm{M} 12$ & 3 & -2.33 & -7.00 & -3.03 \\
\hline
\end{tabular}

Source: Authors

Note: All prices in natural logarithms

\subsection{Time-series econometric analysis}

A standard ADF was used to test for unit roots in both price series. However, considering the potential presence of structural breaks in the series, the unit root test with structural breaks (URSB) proposed by Saikkonen and Lütkepohl (2002) was also employed. Two specifications are considered for the ADF test. One includes only an intercept, and the other includes a trend and intercept. For the URSB test, the specification includes a shift or a shift and a trend. The optimal number of lags is selected using the Schwarz criterion. As reported in Table 3, the results of the ADF and the URSB test indicate that there is insufficient evidence to reject the null hypothesis of nonstationarity at the $5 \%$ level, confirming the presence of unit roots in both the producer and wholesaler price series.

Considering the results of the ADF and URSB tests presented in Table 3, which indicate that both WP and PP are nonstationary, a Johansen cointegration test was employed to test whether they were cointegrated (Johansen 1988, 1995). However, since we suspected the presence of a structural break in the relationship between these prices in January 2006, a modified test proposed by Johansen et al. (2017) for cointegration in the presence of structural breaks was also

Table 4 Johansen trace tests of cointegration between WP and PP with and without a break in January 2006

\begin{tabular}{lllllll}
\hline \multicolumn{2}{l}{ Test without a break } & & & \multicolumn{2}{l}{ Test with a break in January 2006} \\
\cline { 1 - 3 } \cline { 5 - 7 } $\begin{array}{l}\text { Null } \\
\text { hypothesis }\end{array}$ & $\begin{array}{l}\text { Trace } \\
\text { statistic }\end{array}$ & $p$ value & & $\begin{array}{l}\text { Null } \\
\text { hypothesis }\end{array}$ & $\begin{array}{l}\text { Trace } \\
\text { statistic }\end{array}$ & $p$ value \\
\hline $\mathrm{r}=0$ & 22.71 & 0.020 & $\mathrm{r}=0$ & 29.32 & 0.008 \\
$\mathrm{r}=1$ & 1.26 & 0.900 & $\mathrm{r}=1$ & 8.66 & 0.220 \\
\hline
\end{tabular}

Tests carried out with prices in natural logarithms and with three lags according to the Schwarz criterion conducted. The results of both tests, which are presented in Table 4, suggest that there is a long-run cointegrating relationship between the WP and PP.

To assess the dynamic interactions between the producer and wholesale prices we first estimated a VECM using the full sample. Since the media search presented above suggests that structural changes took place at the beginning of 2006, which is corroborated by the results of the cointegration test with structural break in January 2006, we performed break point and sample split Chow tests (Candelon and Lütkepohl 2001) on the residuals of this VECM. The test statistics and corresponding bootstrap $p$ values are reported in Table 5. The results add to the evidence that the price behavior in the Panamanian milk market changed fundamentally in early 2006.

Based on the results of the market structure analysis and the empirical tests above, we estimated the VECM described in eq. (1) above, which includes a structural break in January 2006. This VECM includes an intercept shift in the constant term of the cointegration vector to capture a shift in the price spread between producer and wholesale prices.

The results of the VECM model in Table 6 indicate that in the long run a change of $1 \%$ in the wholesaler price leads to a change of $0.45 \%$ in the producer price. The loading

Table 5 Results of Chow tests for structural breaks in the VECM model residuals

\begin{tabular}{lllll}
\hline $\begin{array}{l}\text { Break } \\
\text { Date }\end{array}$ & Test & $\begin{array}{l}\text { Test } \\
\text { Statistic }\end{array}$ & $\begin{array}{l}\text { Bootstrapped } \\
\mathrm{d} p \text { value }\end{array}$ & $\begin{array}{l}\text { Asymptotic } \\
\mathrm{Chi}^{2} p \text { value }\end{array}$ \\
\hline $2006 \mathrm{M1} 1$ & $\begin{array}{l}\text { Break Point } \\
\text { Chow test (BP) } \\
\text { Sample Split } \\
\text { Chow test (SS) }\end{array}$ & 311 & 0.00 & 0.00 \\
& 13 & 0.09 & 0.09 \\
\hline
\end{tabular}

Source: Authors

Bootstrap $p$-values based on 100 replications; sample period 1991 M3 to 2013 M12 
Table 6 VECM parameter estimates

\begin{tabular}{lll}
\hline Long-run PT elasticity & $\hat{b}_{2}$ & $-0.45^{* * *}$ \\
& & $(0.13)$ \\
PP speed of adjustment & $\hat{\alpha}_{1}$ & $-0.23^{* * *}$ \\
& & $(0.04)$ \\
WP speed of adjustment & $\hat{\alpha}_{2}$ & $0.16^{* * *}$ \\
& & $(0.05)$ \\
Price spread & $\hat{\mu}$ & $-1.71^{* * *}$ \\
& & $(0.44)$ \\
Structural change & $\hat{\delta}$ & $-0.30^{* * *}$ \\
dummy & & $(0.08)$ \\
\hline
\end{tabular}

Source: Authors

Numbers in parentheses are standard errors. $* * *$ denotes statistical significance at the $1 \%$ level; $* *$ denotes statistical significance at the $5 \%$ level; * denotes statistical significance at the $10 \%$ level

coefficients show that both producer and wholesale prices adjust to correct deviations from this long run equilibrium at average rates of $23 \%$ and $16 \%$ per month, respectively. As the intercept and the intercept shift are in logs, we take their anti$\operatorname{logs}$ to interpret them. The exponential value of the intercept $\hat{\mu}=-1.71$ indicates that the marketing margin between wholesale and producer prices is equivalent to a mark-up of approximately $18 \%$ on the latter. Furthermore, the exponential value of the market-structure change dummy $\hat{\delta}=-0.30$ indicates that this mark-up dropped to $13 \%$ after 2006 . These results complement previous analysis of PT on the milk market in Panama (Acosta and Valdés 2014), showing that although a cointegrating relationship between producers and wholesalers' prices exists, the speed of adjustment is relatively slow.

\subsection{Triangulation of both analyses}

The results derived from each of the two previous methodologies, qualitative examination of the market structure, and econometric assessment of price interrelationships, are combined in Table 7 to generate insights into how market structure and the behavior of agents are affecting PT.

The results of the market structure analysis confirm the first proposition that the milk market in Panama is characterized by an oligopsonistic structure, with 6,630 producers facing six major processors, of which the four largest account for $90 \%$ of the milk supplied to industrial processing $\left(C R_{4}=0.90\right)$. Furthermore, the semi-structured interview with ACODECO revealed that these four processors were found guilty of having exchanged information to set a lower farm-gate prices for raw milk.

The results of the VECM long-term parameter confirm the second proposition indicating that the transmission of milk prices from wholesaler to producers is damped. According to the long-run PT elasticity parameter, a change of $1 \%$ in the wholesale price leads to a change of $0.45 \%$ in the producer price. Since the share cost of raw milk in the final wholesaler price is approximately $80 \%$ we would expect the elasticity of PT to be closer to 0.8 . Hence, the estimated elasticity of 0.45 suggests that price transmission is being damped.

The results of the VECM estimation with a structural change dummy parameter confirm the third proposition, showing how the introduction of competitive measures affected the marketing margin between wholesale and producer prices. This parameter reveals that after antitrust regulations were imposed, the price spread between wholesalers and producers decreased from $18 \%$ to $13 \%$. In other words, the milk producer's share of the wholesaler price increased from $82 \%$ to $87 \%$ after the regulations were imposed.

\section{Conclusions and discussion}

Price dynamics on food markets have important welfare effects and food security implications. Therefore, substantial attention has been devoted in recent decades to the analysis of vertical and horizontal PT. This analysis has traditionally focused on exclusively applying econometric methods. However, the sole application of econometrics has been acknowledged by various authors as having only limited potential to generate concrete insights to support evidence-based policy-making, as it is difficult to make sense of econometric results without a broader understanding of the institutional structure of the market in question. This study contributes to a broadening of the analytical tool kit beyond the sole use of econometrics.

Table 7 Triangulation

\begin{tabular}{lll}
\hline Proposition & Method & Evidence \\
\hline $\begin{array}{l}\text { The market structure is characterized by } \\
\text { oligopsonistic competition }\end{array}$ & $\begin{array}{l}\text { Market Structure } \\
\text { Analysis }\end{array}$ & CR index and semi-structured interviews with ACODECO \\
$\begin{array}{l}\text { Oligopsonistic power dampens the degree of PT } \\
\begin{array}{l}\text { Price spread narrows when markets become more } \\
\text { competitive }\end{array}\end{array}$ & VECM & A change of 1\% in WP prices leads to a change of 0.45\% in PP \\
\end{tabular}

Source: Authors 
We propose and illustrate the application of an analytical framework to facilitate a more comprehensive understanding of price dynamics along food supply chains. The analytical framework is composed of three steps, each of which consist of several tasks. Step 1 employs qualitative analysis of the market of interest to obtain detailed insight into its structure and the existence and magnitude of factors that might affect price dynamics along food supply chain. Step 2 uses timeseries econometrics to quantitatively assess such price dynamics. Step 3 triangulates the results of the two preceding steps to gain comprehensive insight.

The results of the market structure analysis confirm the first proposition showing that the milk market in Panama is characterized by an oligopsonistic structure. Furthermore, the semi-structured interview with ACODECO reveals that a number of processors were found guilty of having set lower farm-gate prices for raw milk. The VECM long-term parameter confirms the second proposition, showing that the longrun PT elasticity (0.45) is lower than expected (0.8), which suggests that the transmission of price changes from wholesalers to producers is being damped. Finally, the structural change dummy of the VECM reveals that, after antitrust regulations were imposed, the price spread between wholesalers and producers decreased from $18 \%$ to $13 \%$, confirming our third proposition. As indicated in the literature one should be wary of inferring too much about the competitive setting of the market based on PT econometric analysis alone. However the combination of quantitative and qualitative analysis shows that there is not only oligopolistic competition but also strong evidence of collusion.

The proposed methodological framework could be extended in several directions. For example, Hassouneh et al. (2012) point out that more insight is needed to better capture the nonlinear behavior of PT processes. In this regard, the use of TVECM or one of its versions could be useful to compare PT when milk powder stocks are below or above certain thresholds. Although our analysis failed to find evidence of seasonal patterns, if milk prices do tend to increase during the dry season and decrease during the rainy season, as suggested by processors in the semi-structured interviews, then model specifications such as those proposed by Amikuzuno and von Cramon-Taubadel (2012), or state space models with timevarying parameters (e.g. Adämmer et al. 2016; Vollmer and von Cramon-Taubadel 2017) could be employed to capture the effects of seasonality in the speed of adjustment.

Further analyses might aim at explaining the exact role of imperfect competition. One might try to better understand "which," "how," and "why" determinants are constraining the transmission of prices along food supply chains. The NEIO literature has suggested a number of market performance measures that could be used to complement the market structure analysis for testing competitive behavior. Examples are rates of returns, price-cost margins or Lerner's measures
(Carlton and Perloff 2004). However, such methods require information related to costs, volumes and prices that is often unavailable. Although these methods are powerful in their theoretical explanatory power, their empirical application is difficult if there is no institutional mechanism which compels stakeholders to disclose such information.

\section{Compliance with ethical standards}

Conflict of interest The authors declare that there is no conflict of interest regarding the publication of this article.

The views expressed in this publication are those of the author(s) and do not necessarily reflect the views or policies of FAO.

Open Access This article is licensed under the terms of the Creative Commons Attribution-NonCommercial-ShareAlike 3.0 IGO License, which permits any non-commercial use, sharing, adaptation, distribution and reproduction in any medium or format, as long as you give appropriate credit to the Food and Agriculture Organization of the United Nations (FAO), provide a link to the Creative Commons licence, and indicate if changes were made. If you remix, transform, or build upon this article or a part thereof, you must distribute your contributions under the same licence as the original.

The use of the Food and Agriculture Organization of the United Nations (FAO)'s name, and the use of the Food and Agriculture Organization of the United Nations (FAO)'s logo, shall be subject to a separate written licence agreement between the Food and Agriculture Organization of the United Nations (FAO) and the user and is not authorized as part of this CC-IGO licence. Note that the link provided above includes additional terms and conditions of the licence.

The images or other third party material in this article are included in the article's Creative Commons licence, unless indicated otherwise in a credit line to the material. If material is not included in the article's Creative Commons licence and your intended use is not permitted by statutory regulation or exceeds the permitted use, you will need to obtain permission directly from the copyright holder.

To view a copy of this licence, visit http://creativecommons.org/licenses/ by-nc-sa/3.0/igo/.

\section{References}

Acosta, A., Ihle, R., \& Robles, M. (2014). Spatial Price Transmission of Soaring Milk Prices from Global to Domestic Markets. Agribusiness, 30, 64-73.

Acosta, A., \& Valdés, A. (2014). Vertical Price Transmission of Milk Prices: Are Small Dairy Producers Efficiently Integrated into Markets? Agribusiness, 30, 56-63.

Adämmer, P., Bohl, M. T., \& Gross, C. (2016). Price Discovery in Thinly Traded Futures Markets. How Thin is Too Thin? In: Journal of Futures Markets, 36(9), 851-869.

Amikuzuno, J., \& von Cramon-Taubadel, S. (2012). Seasonal variation in price transmission between tomato markets in Ghana. Journal of African Economies, 21(4), 669-686.

Armstrong, M., \& Porter, R. H. eds. (2007). Handbook of IO (Vol. 3). Elsevier.

Bakucs, Z., Fałkowski, J., \& Fertö, I. (2014). Does market structure influence PT in the agro-food sector? A meta-analysis perspective. Journal of Agricultural Economics, 65, 1-25.

Berrocal, R. (2006, January 19). Nestlé aumenta los precios de sus productos lácteos. In La Prensa. Retrieved from http://impresa. 
prensa.com/economia/Nestle-aumenta-precios-productos-lacteos 0 1657334426.html.

Bonnet, C., \& Réquillart, V. (2013). Impact of cost shocks on consumer prices in vertically-related markets: the case of the French soft drink market. American Journal of Agricultural Economics, aat055.

Brümmer, B., von Cramon-Taubadel, S., \& Zorya, S. (2009). The impact of market and policy instability on PT between wheat and flour in Ukraine. European Journal of Agricultural Economics, 36(2), 203230

Bulow, J. I., \& Pfleiderer, P. (1983). A note on the effect of cost changes on prices. Journal of Political Economy, 91(1), 182-185.

Busse, S., Brümmer, B., \& Ihle, R. (2012). Price formation in the German biodiesel supply chain: A Markov-switching vector error-correction modeling approach. Agricultural Economics, 43(5), 545-560.

Candelon, B., \& Lütkepohl, H. (2001). On the reliability of Chow-type tests for parameter constancy in multivariate dynamic models. Economics Letters, 73(2), 155-160.

Carlton, D. W., \& Perloff, J. M. (2004). Modern Industrial Organization (4th ed.) Pearson.

Contraloría General de la República de Panamá (CGRP). (2011). VII censo nacional agropecuario, 2011. Ciudad de Panamá: Resultados finales.

Contraloría General de la República de Panamá (CGRP). (2014). Base de datos sobre precios de alimentos de la canasta básica nacional. Ciudad de Panamá.

Davenport, F., \& Funk, C. (2015). Using time series structural characteristics to analyze grain prices in food insecure countries. Food Security, 7(5), 1055-1070.

Dawe, D., \& Maltsoglou, I. (2014). Marketing margins and the welfare analysis of food price shocks. Food Policy, 46, 50-55.

De Gracia, M. (2008, March 31). Demandan a empresas lácteas debido a supuesto monopolio. In Panamá América. Retrieved from http:// www.panamaamerica.com.pa/content/demandan-empresas-1\%C3\% A1cteas-debido-supuesto-monopolio.

Enders, W. (1998). Applied econometric time series. Inc: John Wiley \& Sons.

Engel, R., \& Granger, C. (1987). Cointegration and error correction: representation, estimation, and testing. Econometrica, 55(2), 251276.

Esposti, R., \& Listorti, G. (2013). Agricultural price transmission across space and commodities during price bubbles. Agricultural Economics, 44(1), 125-139.

Fabinger, M., \& Weyl, G. (2013). Pass-through as an economic tool: principles of incidence under imperfect competition. Journal of Political Economy, 121(3), 528-583.

Fackler, P.L. \& Goodwin, B.K. (2001). Spatial price analysis. In: Handbook of Agricultural Economics, ed. Gardner, B.L. \& Rausser, G.C., 971-1024. Amsterdam: Elsevier Science.

Food and Agriculture Organization of the United Nations - FAO. (2012). The state of agricultural markets. Rome, 2012.

Frey, G., \& Manera, M. (2007). Econometric models of asymmetric price transmission. Journal of Economic Surveys, 21(2), 349-415.

Gardner, B. L. (1975). The farm-retail price spread in a competitive food industry. American Journal of Agricultural Economics, 57(3), 399409.

Goodwin, B. K., \& Vavra, P. (2009). What can we learn from spatial and vertical price transmission studies? Empirical examples from U.S. meat markets. Paper prepared for the Courant Research Centre Poverty, Equity and Growth Inaugural Conference at the University of Gottingen, Germany.

Granger, C. (1981). Some properties of time series data and their use in econometric model specification. Journal of Econometrics, 16(1), $121-130$.

Guerra, D. (2006a, November 22). Lecheros denuncian monopolio de precios. La Prensa. Retrieved from http://impresa.prensa.com/
economia/Lecheros-denuncian-monopolio-precios_0_1887561357. html.

Guerra, D. (2006b, September 11). Lecheros inician negociación con industriales. La Prensa. Retrieved from http://impresa.prensa.com/ economia/Lecheros-inician-negociacion-industriales_0_ 1850815008.html.

Hassouneh, I., Serra, T., Goodwin, B., \& Gil, J. M. (2010). Nonparametric and parametric modelling of biodiesel, sunflower oil, and crude oil price relationships. Energy Economics, 34(5), 15071513.

Hassouneh, I., von Cramon-Taubadel, S., Serra, T., \& Gil, J. M. (2012). Recent developments in the econometric analysis of price transmission. Transparency of Food Pricing Working Paper, 2 available at eforenergy.org/docpublicaciones/documentos-de-trabajo/WPFA062013.pdf.

Hong, G. H., \& Li, N. (2017). Market structure and cost pass-through in retail. Review of Economics and Statistics, 99(1), 151-166.

Hovhannisyan, V., \& Bozic, M. (2014). Retailer Motivation to Adjust Milk Prices: An Analysis Using Superelasticity of Demand. Agribusiness, 30(2), 195-206.

Ihle, R., Brümmer, B., \& Thompson, S. R. (2012). Structural change in European calf markets: Decoupling and the blue tongue disease. European Review of Agricultural Economics, 39(1), 157-180.

Instituto nacional de estadística y censo de Panama (INEC). (2014). Estimacion de la produccion de leche de vaca en la Republica de Panama: 1993-2013.

Johansen, S. (1988). Statistical analysis of cointegration vectors. Journal of Economic Dynamics and Control, 12(2-3), 231-254.

Johansen, S. (1991). Estimation and hypothesis testing of cointegration vectors in Gaussian vector autoregressive models. Econometrica, 59(6), 1551-1580.

Johansen, S. (1995). A statistical analysis of cointegration for I (2) variables. Econometric Theory, 11(1), 25-59.

Johansen, S., Mosconi, R., \& Nielsen, B. (2017). Cointegration analysis in the presence of structural breaks in the deterministic trend. Econometrics Journal, volume, 3, 216-249.

Kim, D., \& Cotterill, R. W. (2008). Cost pass-through in differentiated product markets: The case of US processed cheese. The Journal of Industrial Economics, 56(1), 32-48.

König, H. J., Graef, F., Schindler, J., et al. (2017). Combining participatory, qualitative and quantitative methods for impact assessment of food value chains into an integrated framework. Food Security, 9, 1 13.

Lloyd, T. (2017). Forty Years of PT Research in the Food Industry: Insights, Challenges and Prospects. Journal of Agricultural Economics, 68(1), 3-21.

Luckmann, J., Ihle, R., Kleinwechter, U., \& Grethe, H. (2015). World market integration of Vietnamese rice markets during the 2008 food price crisis. Food security, 7(1), 143-157.

McCorriston, S. (2013). Transparency of Food Pricing. TRANSFOP. Paper prepared as the OECD Secretariat background paper for the OECD Competition Roundtable in Paris for the special session on "Competition in the Food Chain".

McCorriston, S., Morgan, C. W., \& Rayner, A. J. (1998). Processing technology, market power and PT. Journal of Agricultural Economics, 49(2), 185-201.

Meyer, J., \& von Cramon-Taubadel, S. (2004). Asymmetric Price Transmission: a survey. Journal of Agricultural Economics, 55(3), 581-611.

Miller, D. J., \& Hayenga, M. L. (2001). Price cycles and asymmetric price transmission in the U.S. pork market. American Journal of Agricultural Economics, 83(3), 551-562.

Ministerio de Desarrollo Agropecuario (MIDA). (2011). Resolución DAL No. 018-ADM-2011. Gaceta Oficial. Panama, Mayo, 2011. 
Organization for Economic Co-operation and Development - OECD. (2015). Food Price Formation. 7th Food Chain Analysis Network Meeting. Paris, (October 2015).

Peltzman, S. (2000). Prices rise faster than they fall. Journal of Political Economy, 108(3), 466-502.

Perron, P. (1989). The great crash, the oil price shock, and the unit root hypothesis (pp. 1361-1401). Econometrica: Journal of the Econometric Society.

Saikkonen, P., \& Lütkepohl, H. (2002). Testing for a unit root in a time series with a level shift at unknown time. Econometric Theory, 18, 313-348.

Serra, T., \& Goodwin, B. K. (2002). Price transmission and asymmetric adjustment in the Spanish dairy sector. 2002 Annual meeting, 28-31 July, Long Beach, California, American Agricultural Economics Association.

Sexton, R. J., \& Lavoie, N. (2001). Food processing and distribution: an industrial organization approach. Handbook of agricultural economics, 1, 863-932.

Sutton, J. (1991). Sunk costs and market structure: Price competition, advertising, and the evolution of concentration. MIT press.

Tapia, S. (2007a, June 7). Lecheros advierten de aumento al consumidor. La Prensa. Retrieved from http://impresa.prensa.com/economia/ Lecheros-advierten-aumento-consumidor_0_2035296658.html).

Tapia, S. (2007b, June 5). Empresas no acogen peticiones de productores. La Prensa. Retrieved from http://impresa.prensa.com/economia/ Empresas-acogen-peticiones-productores_0_2033796781.html.

Tapia, S. (2007c, June 7). Lecheros aceptaron la propuesta de aumento. La Prensa. Retrieved from http://impresa.prensa.com/economia/ Lecheros-aceptaron-propuesta-aumento_0_2035296672.html.

Torres, V. (2007, May 22). El paro de los lecheros desabastecerá la industria. La Prensa. Retrieved from http://impresa.prensa.com/ economia/paro-lecheros-desabastecera-industria_0_2023297843. html.

Usman, M. A., \& Haile, M. G. (2017). Producer to retailer price transmission in cereal markets of Ethiopia. Food Security, 9(4), 815-829.

Vollmer, T. \& von Cramon-Taubadel, S. (2017). Price discovery in the European wheat market. Conributed paper presented at the XV EAAE Congress, "Towards Sustainable Agri-food Systems: Balancing Between Markets and Society" Parma, Italy, August 29th - September 1st.

von Cramon-Taubadel, S. (2017). The analysis of market integration and price transmission - results and implications in an African context. Agrekon, 56(2), 83-96.

Wang, D., \& Tomek, W. (2007). Commodity prices and unit root tests. American Journal of Agricultural Economics, 89(4), 873-889.

Weldegebriel, H. T. (2004). Imperfect price transmission: Is market power really to blame? Journal of Agricultural Economics, 55, 101-114.

Würriehausen, N., Ihle, R., \& Lakner, S. (2015). Price Relationships Between Qualitatively Differentiated Agricultural. Products: Organic and Conventional Wheat in Germany. Agricultural Economics. https://doi.org/10.1111/agec.12151.

Yin, R. (2013). Case study research: Design and methods. London: Sage publications, Inc.

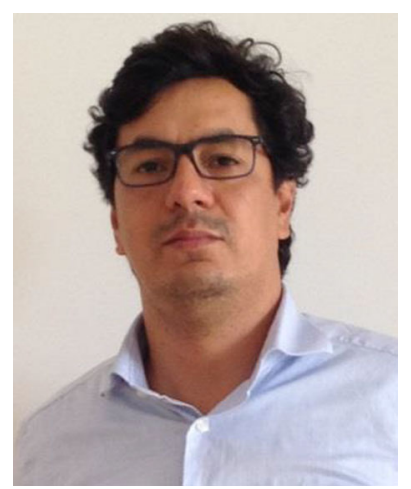

Alejandro Acosta is an Agricultural Economist and Policy Officer at the Food and Agriculture Organization of the United Nations (FAO). He holds a $\mathrm{PhD}$ in Agricultural Economics from the University of Göttingen, Germany. His research interests include the analysis of agricultural policies in developing countries, market integration, and productivity analysis.

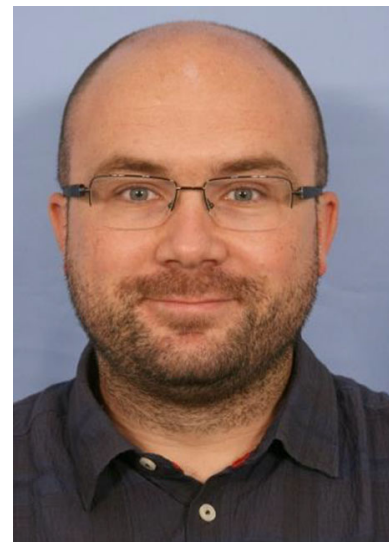

Rico Ihle is Assistant Professor in the Agricultural Economics and Rural Policy Group of Wageningen University, The Netherlands. He holds a $\mathrm{PhD}$ in agricultural economics from the University of Göttingen, Germany. His research interests include the analysis of prices of agricultural and food products, economic aspects of violent political conflict, the evaluation of the effects of public policies on food markets and the analysis of food markets in the Middle East and Sub-Saharan Africa.

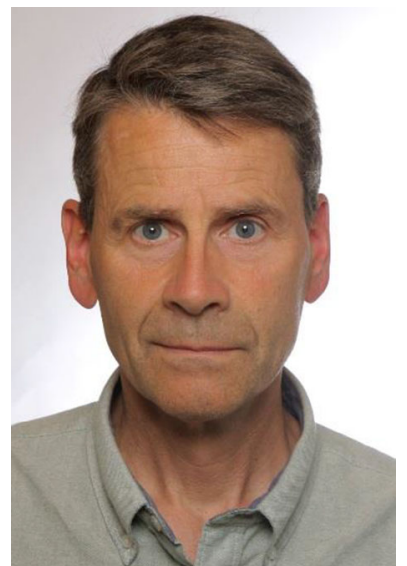

Stephan von Cramon-Taubadel is Professor in the Department of Agricultural Economics and Rural Development of the University of Göttinen in Germany. He holds a $\mathrm{PhD}$ in agricultural economics from the University of Kiel in Germany. His research interests include the analysis of market integration, agricultural policy in the European Union, agricultural transformation processes, for example in the Former Soviet Union, and interactions between agriculture and the environment. 